
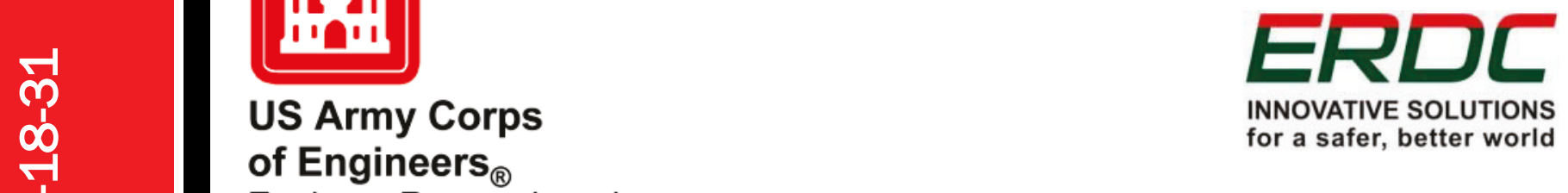

INNOVATIVE SOLUTIONS

for a safer, better world

Engineer Research and

Development Center

Engineer Site Identification for the Tactical Environment (ENSITE)

\title{
Selection Parameters Used in the Touchdown Point Selection Module for ENSITE
}

Joseph A. Gamez, Patrick J. Guertin, Eric L. Kreiger, and

September 2018

George W. Calfas

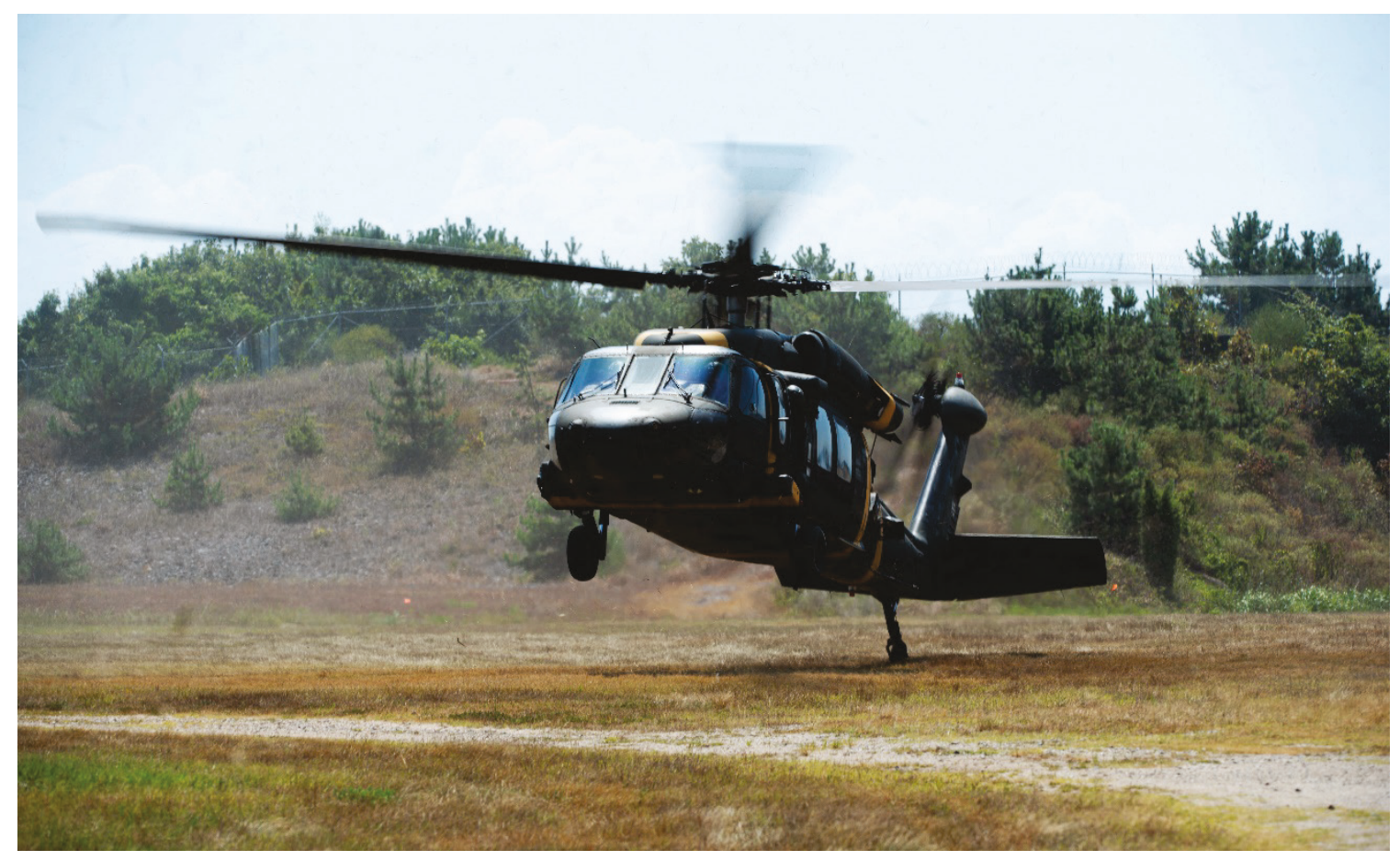


The U.S. Army Engineer Research and Development Center (ERDC) solves the nation's toughest engineering and environmental challenges. ERDC develops innovative solutions in civil and military engineering, geospatial sciences, water resources, and environmental sciences for the Army, the Department of Defense, civilian agencies, and our nation's public good. Find out more at www.erdc.usace.army.mil.

To search for other technical reports published by ERDC, visit the ERDC online library at http://acwc.sdp.sirsi.net/client/default. 


\section{Selection Parameters Used in the Touchdown Point Selection Module for ENSITE}

Joseph A. Gamez, Patrick J. Guertin, Eric L. Kreiger and George W. Calfas

U.S. Army Engineer Research and Development Center (ERDC)

Construction Engineering Research Laboratory (CERL)

2902 Newmark Drive

Champaign, IL 61822

Final Report

Approved for public release; distribution is unlimited.

Prepared for Assistant Secretary of the Army for Acquisition, Logistics and Technology (ASA(ALT))

103 Army Pentagon

Washington, DC 20314-1000

Under Project \#455009, “Military Facilities Engineering Technology" 


\section{Abstract}

The Army must have the ability to rapidly plan and locate engineered sites, such as soldier base camps or airfields, for supporting maximum combat effectiveness of deployed forces. By defining mission-specific site requirements prior to force deployment and facility locations and construction, Army commanders and planners are able to optimize various siting and design decisions. This report details the design steps used to develop the Touchdown Point (TDP) Module in the Engineer Site Identification for the Tactical Environment (ENSITE) remote planning tool. The module is used for preliminary design and siting of TDPs for landing helicopters. Since the TDP module within ENSITE is a remote planning tool for a very specific set of design criteria, this work presents the rationale for why the module makes certain assumptions, how it calculates certain quantities, and where it obtains its data.

DISCLAIMER: The contents of this report are not to be used for advertising, publication, or promotional purposes. Citation of trade names does not constitute an official endorsement or approval of the use of such commercial products. All product names and trademarks cited are the property of their respective owners. The findings of this report are not to be construed as an official Department of the Army position unless so designated by other authorized documents. 


\section{Contents}

Abstract.................................................................................................................................. if

Figures and Tables.............................................................................................................iv

Preface ..................................................................................................................

Unit Conversion Factors...........................................................................................vi

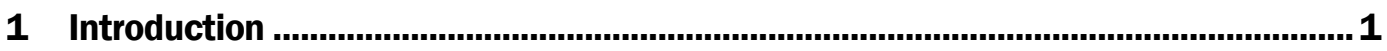

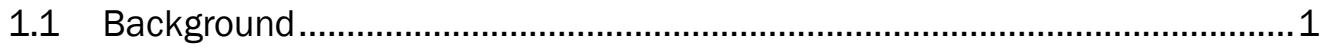

1.2 Objective........................................................................................ 2

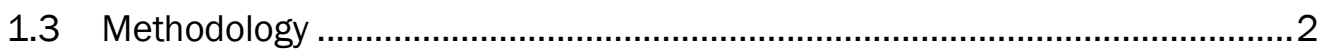

2 Considerations for Siting Touchdown Points........................................................ 3

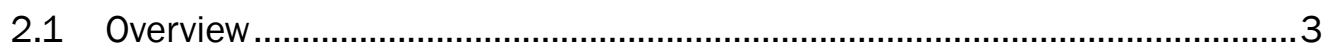

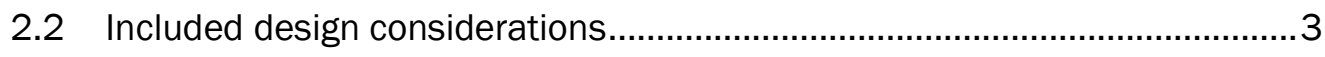

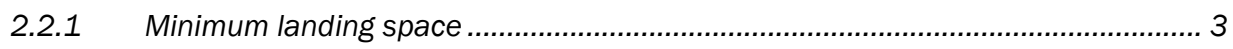

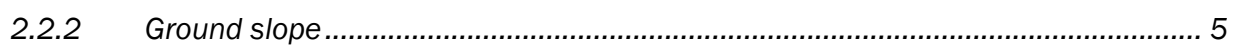

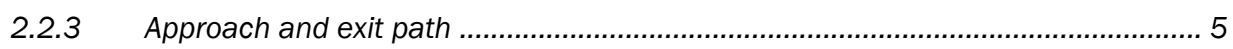

2.3 Design components excluded ............................................................... 6

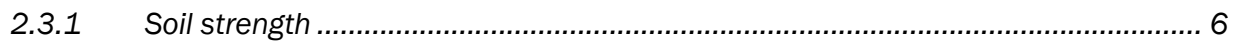

2.3.2 Other design considerations ................................................................................. 8

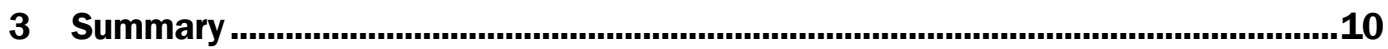

References.....................................................................................................................11 


\section{Figures and Tables}

\section{Figures}

Figure 1. Touchdown Point sizes (from FM 3-21.38 2006, p. 4-2)...................................... 4

Figure 2. Approach and exit path, taken from FM 3-21.38 (2006, p. 4-8). It should be noted that "DIMENSION X" referred to in the figure refers to night operations, which are not included in this iteration of the TDP module.

Figure 3. Design chart used to determine the number of times a helicopter can land at a TDP (from TM 3-34.48-2 (2016), pg. 5-15).

\section{Tables}

Table 1. TDP specifications.

4

Table 2. Estimated CBR values for Unified Soil Classification System (USCS)

soils, modified after ARA Inc. (2001, p. CC 1-10, Table 5).................................................... 7

Table 3. TDP siting considerations not included in the TDP module.................................... 9 


\section{Preface}

This study was conducted for Assistant Secretary of the Army for Acquisition, Logistics and Technology (ASA(ALT)) under T45, "Military Facilities Engineering Technology" and Project Number 455009, "Contingency Base Site Identification Tool for the Tactical Environment." The technical monitor was Mr. Kurt Kinnevan, CEERD-CZT.

The work was performed under supervision of the Environmental Processes Branch (CNE) of the Installation Division (CN), U.S. Army Engineer Research and Development Center, Construction Engineering Research Laboratory (ERDC-CERL). At the time of publication, Mr. H. Garth Anderson was Chief, CEERD-CNE; Ms. Michelle Hanson was Chief, CEERD-CN; and Mr. Kurt Kinnevan, CEERD-CZT was the Technical Director for Infrastructure for Combat Operations. The Deputy Director of ERDC-CERL was Dr. Kirankumar Topudurti, and the Director was Dr. Lance D. Hansen.

COL Ivan P. Beckman was Commander of ERDC, and Dr. David W. Pittman was the Director. 


\section{Unit Conversion Factors}

\begin{tabular}{|l|l|l|}
\hline Multiply & By & To Obtain \\
\hline degrees (angle) & 0.01745329 & radians \\
\hline degrees Fahrenheit & $(\mathrm{F}-32) / 1.8$ & degrees Celsius \\
\hline feet & 0.3048 & meters \\
\hline pounds (mass) & 0.45359237 & kilograms \\
\hline
\end{tabular}




\section{Introduction}

\subsection{Background}

The U.S. Army must have an ability to rapidly plan and locate engineered sites, such as soldier base camps or airfields, for supporting maximum combat effectiveness of deployed forces. By defining mission-specific site requirements prior to force deployment and facility locations and construction, Army commanders and planners are able to optimize various siting and design decisions.

This report was developed to document the technical data for use in the development of the planned Touchdown Point (TDP) module in the Engineer Site Identification for the Tactical Environment (ENSITE) remote planning tool. TDPs are defined by Unified Facilites Criteria (UFC) 3-26001 (2008, p. 249) as a "[d]esignated location...for permitting more rapid launch or recovery of helicopters" and are also known as landing points. To site a TDP, the ENSITE TDP module uses technical parameters and tactics, techniques, and procedures that are extracted from Field Manual (FM) 3-21.38 (2006), Technical Manual (TM) 3-34.48-2 (2016), and UFC 3-260-01 (2008). Since the TDP module is focused on the tactical environment, however, its methodology draws heavily from FM 5-430-00-2 (1994), "Planning and Design of Roads, Airfields, and Heliports in the Theater of Operations-Airfield and Heliport Design." It should be noted that, at the time of this report, the TDP module is limited to siting one TDP per candidate location rather than multiple TDPs.

ENSITE, developed at the Engineer Research and Development CenterConstruction Engineering Research Laboratory (ERDC-CERL), is a geographic information system (GIS)-based computer program that enables military planners to remotely site and plan encampments and their related infrastructure. ENSITE does this by providing military planners with modules that provide key planning parameters, such as soil and weather, or recommendations for construction, such as the optimal location for a soil runway. The TDP module gives the ENSITE tool the capability to site TDPs for rotary-winged aircraft. 


\subsection{Objective}

This report's objective is to provide the military planner with the scientific and doctrinal basis used by the ENSITE TDP module to enable better information for remotely planning a tactical site location and related infrastructure.

\subsection{Methodology}

Selection of criteria for developing the TDP module consisted of reviewing Department of Defense (DoD) doctrine relating to TDPs and consulting with DoD experts in TDP design considerations for rotary-winged aircraft.

These criteria were then incorporated as parameters for writing the TDP module's software code and incorporating it into the ENSITE remote planning tool. 


\section{Considerations for Siting Touchdown Points}

\subsection{Overview}

There are a number technical and tactical items to consider when siting a TDP, but the majority of these were not used in developing ENSITE's TDP module. FM 3-21.38 (2006), while used heavily for the development of TDPs, is mostly focused on considerations that must be determined on site and in person, but ENSITE is focused instead on remote planning for intheater construction decisions.

Since the authors found much flexibility in the technical and tactical criteria for siting TDPs, work to develop ENSITE's TDP module concentrated on reducing the siting criteria to a minimum by using only those criteria that related to remote planning. This reduction in criteria was done to prevent ENSITE/TDP from outputting so many options that the user would be inundated with unnecessary information. The siting criteria was purposely selected by balancing the information available in ENSITE and the engineering assumptions presented in subsequent sections of this workwith the technical requirements given in FM 3-21.38 (2006).

To explain that purposeful selection, this chapter covers the planning considertions in FM 3-21.38, divided into considerations that are included in the TDP module and those that are not. Considerations that apply to the TDP module are accompanied with technical specifications for their implementation.

\subsection{Included design considerations}

\subsubsection{Minimum landing space}

For siting TDPs remotely, FM 3-21.38 (2006, p. 4-1, para. 4-3) recommends using certain measurements and surface criteria to determine TDP size and appropriateness of site (Figure 1). Note that Figure 1 presents the TDP size in relation to Size Groups, as designated by FM 3-21.38 (2006) Size Groups categorize helicopters by size, function, or both and then relate those categories to the diameter of the TDP (e.g., an AH 64A Apache is in Group 3; a Group 3 TDP has an overall diameter of $50 \mathrm{~m}$ ). The TDP groups and corresponding aircraft can be found in Table 1. 
Figure 1. Touchdown Point sizes (from FM 3-21.38 2006, p. 4-2).

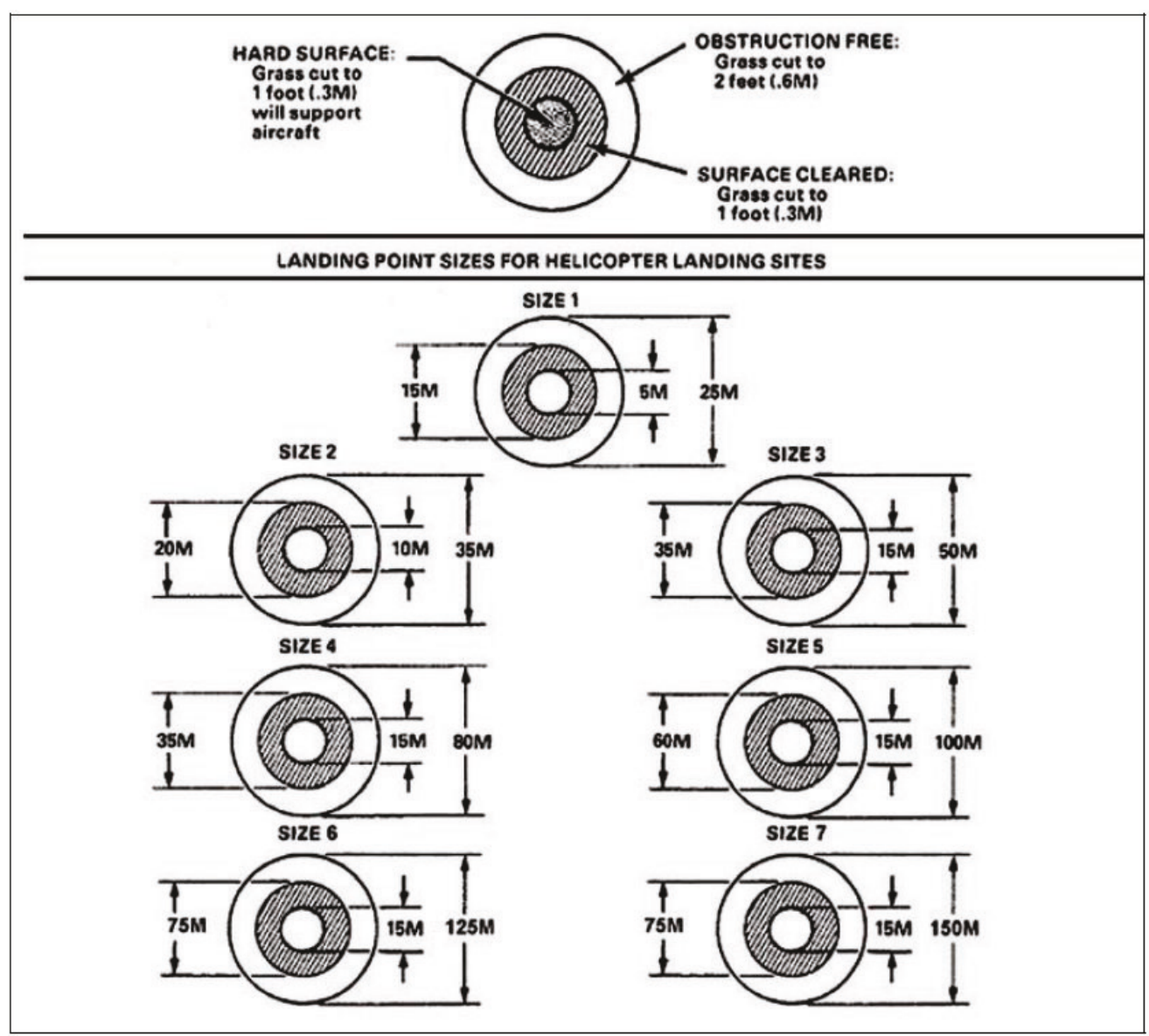

Table 1. TDP specifications.

\begin{tabular}{|l|l|l|l|}
\hline $\begin{array}{l}\text { Size } \\
\text { Group No. }\end{array}$ & $\begin{array}{l}\text { Minimum TDP } \\
\text { Diameter }\end{array}$ & Type of Helicopter or Operation & Model of Helicopter \\
\hline 1 & $80 \mathrm{ft}(25 \mathrm{~m})$ & Light observation helicopters & OH-6, OH-58D \\
\hline 2 & $125 \mathrm{ft}(35 \mathrm{~m})$ & Light utility and attack helicopters & UH-1H, H-65, AH-1W \\
\hline 3 & $160 \mathrm{ft}(50 \mathrm{~m})$ & Medium utility and attack helicopters & UH-60, H-2, AH-64 \\
\hline 4 & $265 \mathrm{ft}(80 \mathrm{~m})$ & Cargo helicopters & $\mathrm{CH}-47, \mathrm{CH}-53$ \\
\hline 5 & $328 \mathrm{ft}(100 \mathrm{~m})$ & $\begin{array}{l}\text { Sling load helicopters or helicopters } \\
\text { of unknown origin }\end{array}$ & - \\
\hline 6 & $410 \mathrm{ft}(125 \mathrm{~m})$ & Sling load long-line operations & - \\
\hline 7 & $492 \mathrm{ft}(150 \mathrm{~m})$ & $\begin{array}{l}\text { Sling load operations with night } \\
\text { vision goggles }\end{array}$ & - \\
\hline
\end{tabular}




\subsubsection{Ground slope}

Per FM 3-21.38 (2006, p. 4-5, para. 4-13), the ground slope should not exceed $7^{\circ}$. Thus, sites exceeding a slope of $7^{\circ}$ should be excluded from consideration. While there are exceptions for landing helicopters on ground slopes above $7^{\circ}$, those exceptions cannot be sufficiently supported in a remote planning tool because they are case-specific and require detailed knowledge of the landing area.

\subsubsection{Approach and exit path}

FM 3-21.38 (2006) prescribes the approach and exit path per the following:
a 16-degree (277 mils) sector or arc extending outward and is measured from the center of the [TDP] ([Figure 2]). The "V"-shaped approach and exit path is shown by the dashed and dotted line in [Figure 2]. The 4-de- gree maximum obstruction angle applies ot the entire area within the ap- proach and exit path (both the dark and light shaded area) measured from the [TDP] center to a distance of $3000 \mathrm{~m}$.

Sites not conforming to this geometry should be excluded from consideration. 
Figure 2. Approach and exit path, taken from FM 3-21.38 (2006, p. 4-8). It should be noted that "DIMENSION X" referred to in the figure refers to night operations, which are not included in this iteration of the TDP module.

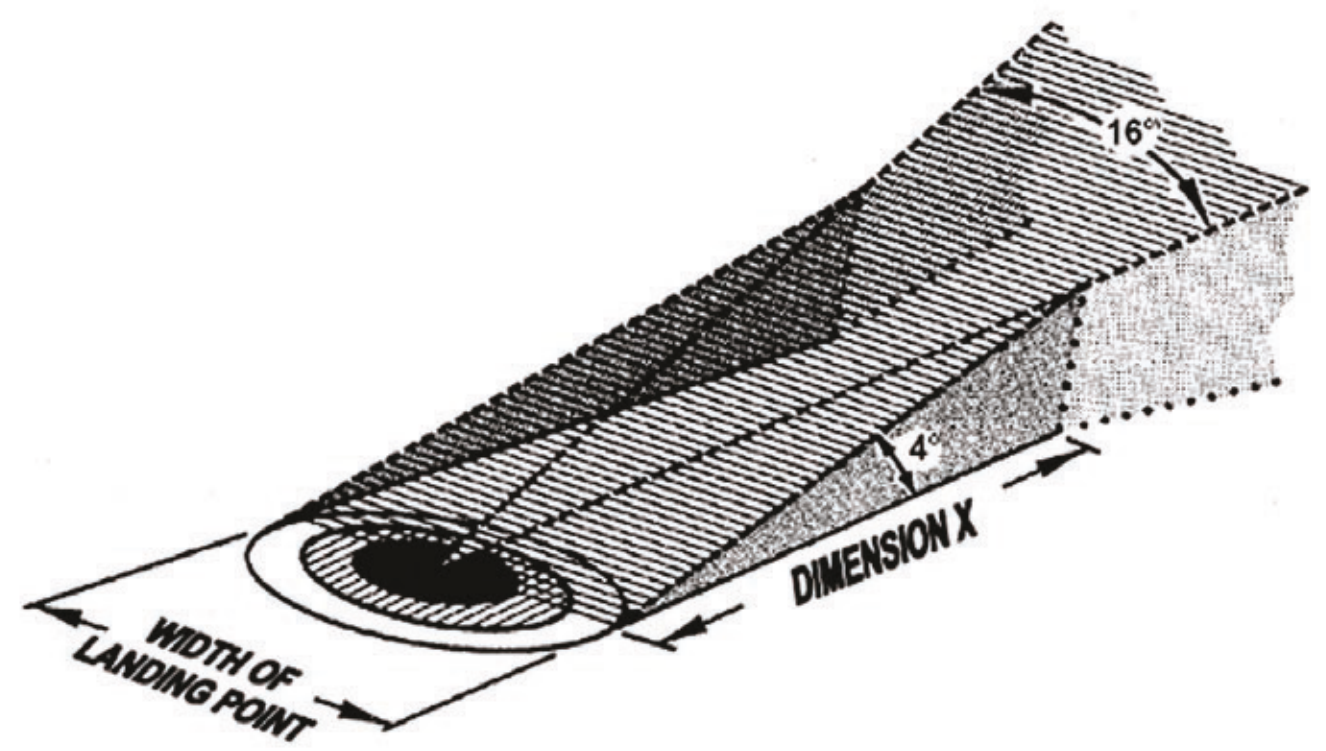

\subsection{Design components excluded}

Because of limitations of GIS systems, a number of planning considerations are omitted in the TDP module's siting methodology. A list of omitted design components and references are presented below.

\subsubsection{Soil strength}

While soil strength at the TDP is an important part of the siting process, it is not explicitly used in the TDP module. This is indeed counterintuitive and, thus, the rationale for removing it is subsequently presented. Adding to the confusion, the issue of soil strength is approached in vastly different ways in FM 3-21.38 (2006) and TM 3-34.48-2 (2016), two of the major publications that drive TDP selection. TM 3-34.48-2 (2016, p. 4-2, para. 46) recommends the Dynamic Cone Penetrometer, a soil probe that provides soil strength readings as an index, to determine if soil strength at the TDP is suitable for landing helicopters. Conversely, FM 3-21.38 (2006, pg. 4-3, para. 4-10) recommends a field-expedient criteria, stating that one should "choose landing sites that have firm surfaces; are free of dust, sand, and debris that might create problems when disturbed by rotor wash ..."

The soil strength criteria is given by TM 3-34.48-2 (2016, p. 5-15) as a design chart which relates a soil strength in the form of a California bearing 
ratio (CBR), ${ }^{1}$ to the number of times a helicopter can take off and land at a TDP (Figure 3). Examining this design chart shows that soil with a CBR of 3 will allow a helicopter weighing up to $50,000 \mathrm{lb}$ to land and take off a combined 10 times. Thus, using a CBR of 3 , a 50,00o lb capacity, and 10 passes as minimum assumptions for planning purposes, the issue of typical soil strength can now be addressed.

Table 2 presents typical CBRs for every soil type. Of all the soil types, highplasticity clays (represented by the symbol $\mathrm{CH}$ ) have the lowest CBR. According to Table 2, a military planner can assume the $\mathrm{CBR}$ of a $\mathrm{CH}$ soil to be at least 3. Going back to the assumptions presented in the previous paragraph, this means that-for planning purposes-even the weakest soil type can be assumed to be satisfactory for landing 50,000 lb helicopters. This assumption eliminates soil strength as a concern and, thus, soil strength is not included as a planning consideration in the TDP module.

Table 2. Estimated CBR values for Unified Soil Classification System (USCS) soils, modified after ARA Inc. (2001, p. CC 1-10, Table 5).

\begin{tabular}{|l|l|}
\hline USCS Symbol & $\begin{array}{l}\text { Estimated } \\
\text { Minimum CBR }\end{array}$ \\
\hline GW & 64 \\
\hline GP & 53 \\
\hline GM & 52 \\
\hline GC & 19 \\
\hline SW & 36 \\
\hline SP & 28 \\
\hline SM & 39 \\
\hline SC & 16 \\
\hline ML & 11 \\
\hline CL & 8 \\
\hline MH & 5 \\
\hline CH & 3 \\
\hline
\end{tabular}

\footnotetext{
1 The CBR is a penetration test for evaluation of the mechanical strength of soil. It was developed by the California Department of Transportation before World War II.
} 
Figure 3. Design chart used to determine the number of times a helicopter can land at a TDP (from TM 3-34.48-2 (2016), pg. 5-15).

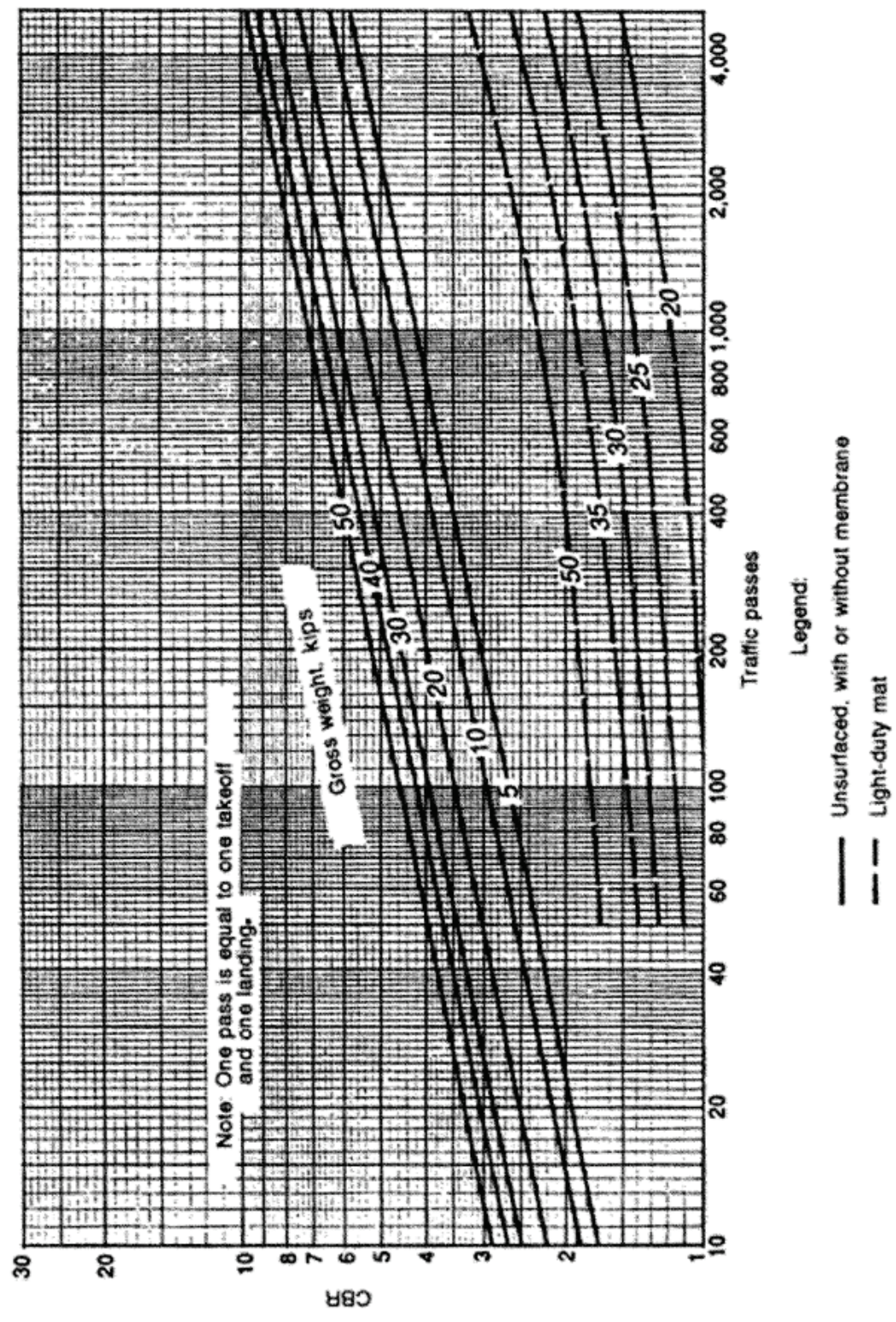

\subsubsection{Other design considerations}

In addition to not including soil strength, as discussed above, there are a number of tactical and technical considerations that are not included in this iteration of the TDP module, as discussed in section 2.1. These considerations are presented in Table 3 . These considerations were omitted primarily because they do not fit the remote scope of the TDP module. For completeness, however, the considerations are mentioned here along with their references in case a military planner might have questions or concerns about the ommitted criteria. 
Table 3. TDP siting considerations not included in the TDP module.

\begin{tabular}{|l|l|l|}
\hline Consideration & Reference & Notes \\
\hline Tactical & $\begin{array}{l}\text { FM 3-21.38 (2006, } \\
\text { p. 4-1, para. 4-2) }\end{array}$ & $\begin{array}{l}\text { Tactical considerations are an } \\
\text { inherent part of the planning } \\
\text { process. They cannot, however, be } \\
\text { codified in a computer program, so } \\
\text { they are omitted. }\end{array}$ \\
\hline $\begin{array}{l}\text { Number of } \\
\text { helicopters }\end{array}$ & $\begin{array}{l}\text { FM 3-21.38 (2006, p. } \\
\text { 4-1, para. 4-4) }\end{array}$ & $\begin{array}{l}\text { This iteration of the TDP module } \\
\text { was developed for siting 1 TDP (i.e., } \\
\text { only one helicopter can land at a } \\
\text { time). }\end{array}$ \\
\hline Landing formations & $\begin{array}{l}\text { FM 3-21.38 (2006, p. } \\
\text { 4-3, para. 4-8) }\end{array}$ & $\begin{array}{l}\text { This iteration of the TDP module } \\
\text { was developed for siting 1 TDP. }\end{array}$ \\
\hline Density altitude* & $\begin{array}{l}\text { FM 3-21.38 (2006, } \\
\text { p. 4-9, para. 4-21) }\end{array}$ & $\begin{array}{l}\text { The FM states that issues regarding } \\
\text { density altitude should be } \\
\text { coordinated with the aviation unit } \\
\text { commander. }\end{array}$ \\
\hline Loads & $\begin{array}{l}\text { TM 3-34.48-2 (2016, p. p. } \\
\text { 4-9, para. 4-22) }\end{array}$ & $\begin{array}{l}\text { This criteria is at the discretion of } \\
\text { the military planner. }\end{array}$ \\
\hline Obstacles & $\begin{array}{l}\text { TM 3-34.48-2 (2016, } \\
\text { p. 4-10, para. 4-23) }\end{array}$ & $\begin{array}{l}\text { This consideration refers generally } \\
\text { rocks, stumps, holes, etc.). This } \\
\text { type of information cannot } \\
\text { accurately be obtained using } \\
\text { remote planning software. }\end{array}$ \\
\hline
\end{tabular}

* Density altitude is pressure altitude corrected for nonstandard temperature. (As temperature and altitude increase, air density decreases.) 


\section{Summary}

This document provides the technical specifications required to develop the code and to implement the TDP module in ENSITE. At the time of publishing, however, the additional code has not been completed within the ENSITE software.

This report was based on technical considerations contained in FM 5-430oo-2 (1994), FM 3-21.38 (2006), UFC 3-260-01 (2008), and TM 3-34.482 (2016). Because ENSITE is a software tool for remote planning, technical parameters are limted to those that can be derived from data obtained from remotely obtained or existing sources (e.g., GIS databses and remote sensed imagery). Technical parameters do include minimum landing space, ground slope, and approach and exit paths.

This document complements ERDC/CERL TR-18-27, Parameters Used in the Tactical Airfield Siting Selection Module for ENSITE (2018), which provides the technical documention required to develop fixed-wing landing sites for ENSITE. 


\section{References}

ARA, Inc. 2001. Guide for Mechanistic-Empirical Design of New and Rehabilitated Pavement Structures. Publication written for and funded by National Cooperative Highway Research Program (NCHRP) of Transportation Research Board, National Research Council. Champaign, IL: Applied Research Associates Inc., ERES Division.

FM 3-21.38. 2006. Pathfinder Operations. Field manual. Washington, DC: Headquarters, Department of the Army.

FM 5-430-00-2. 1994. Planning and Design of Roads, Airfields, and Heliports in the Theater of Operations-Airfield and Heliport Design. Field manual. Washington, DC: Headquarters, Department of the Army.

Gamez, Joseph A., Patrick J. Guertin, Eric L. Kreiger, and George W. Calfas. Parameters Used in the Tactical Airfield Siting Selection Module for ENSITE. ERDC/CERL TR-18-27. Champaign, IL: Engineer Research and Development Center Construction Engineering Research Laboratory (ERDC-CERL).

TM 3-34.48-2. 2016. Theater of Operations: Roads, Airfields, and Heliports-Airfield and Helifport Design. Technical manual. Washington, DC: Headquarters, Department of the Army.

UFC 3-260-01. 2008. Airfield and Heliport Planning and Design. Unified Facilities Criteria. Washington, DC: U.S. Department of Defense. 


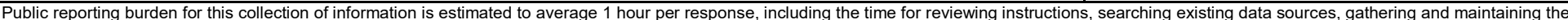

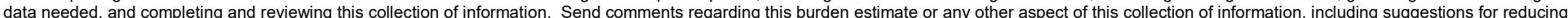

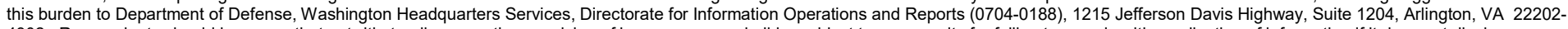

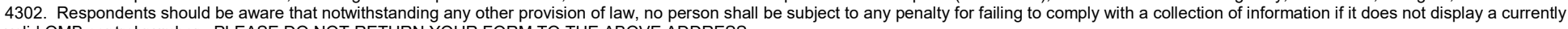
valid OMB control number. PLEASE DO NOT RETURN YOUR FORM TO THE ABOVE ADDRESS.
1. REPORT DATE (DD-MM-YYYY) September 2018 2. REPORT TYPE

\section{TITLE AND SUBTITLE}

Selection Parameters Used in the Touchdown Point Selection Module for ENSITE

6. AUTHOR(S)

Joseph A. Gamez, Patrick J. Guertin, Eric L. Kreiger, and George W. Calfas

\section{DATES COVERED (From - To)}

5a. CONTRACT NUMBER

5b. GRANT NUMBER

5c. PROGRAM ELEMENT NUMBER

$\mathrm{T} 45$

5d. PROJECT NUMBER

455009

5e. TASK NUMBER

\section{5f. WORK UNIT NUMBER}

8. PERFORMING ORGANIZATION REPORT NUMBER

ERDC/CERL TR-18-31

\section{U.S. Army Engineer Research and Development Center (ERDC)}

Construction Engineering Research Laboratory (CERL)

PO Box 9005

Champaign, IL 61826-9005

\section{SPONSORING / MONITORING AGENCY NAME(S) AND ADDRESS(ES)}

Assistant Secretary of the Army for Acquisition, Logistics and Technology 103 Army Pentagon

Washington, DC 20314-1000

\section{SPON}

11. SPONSOR/MONITOR'S REPORT $\operatorname{NUMBER}(\mathbf{S})$

\section{DISTRIBUTION / AVAILABILITY STATEMENT}

Approved for public release. Distribution is unlimited.

\section{SUPPLEMENTARY NOTES}

\section{ABSTRACT}

The Army must have the ability to rapidly plan and locate engineered sites, such as soldier base camps or airfields, for supporting maximum combat effectiveness of deployed forces. By defining mission-specific site requirements prior to force deployment and facility locations and con-struction, Army commanders and planners are able to optimize various siting and design decisions. This report details the design steps used to develop the Touchdown Point (TDP) Module in the Engineer Site Identification for the Tactical Environment (ENSITE) remote planning tool. The module is used for preliminary design and siting of TDPs for landing helicopters. Since the TDP Module within ENSITE is a remote planning tool for a very specific set of design criteria, this work presents the rationale for why the module makes certain assumptions, how it calculates certain quantities, and where it obtains its data.

\section{SUBJECT TERMS}

Military bases-Location, Air bases-Location, Military helicopters, Helicopters-Landing, Geospatial data, Data curation, Computer programs, Military planning, Engineering Site Identification for the Tactical Environment (ENSITE)

\begin{tabular}{|l|c|c|}
\hline \multicolumn{2}{|l|}{ 16. SECURITY CLASSIFICATION OF: } \\
\hline $\begin{array}{c}\text { a. REPORT } \\
\text { Unclassified }\end{array}$ & $\begin{array}{c}\text { b. ABSTRACT } \\
\text { Unclassified }\end{array}$ & $\begin{array}{c}\text { c. THIS PAGE } \\
\text { Unclassified }\end{array}$ \\
\hline
\end{tabular}

\begin{tabular}{c|c|c}
\hline 17. LIMITATION & $\begin{array}{c}\text { 18. NUMBER } \\
\text { OF ABSTRACT }\end{array}$ & 19 \\
OF PAGES & & \\
\cline { 3 - 3 } & 20 & \\
& &
\end{tabular}

19a. NAME OF RESPONSIBLE PERSON

19b. TELEPHONE NUMBER (include area code) 